\title{
The Importance of Metacognitive Listening Strategy in English Listening Improvement: A Review
}

\author{
Alber $^{1)}$, Maria Safriyanti ${ }^{2)}$ \\ ${ }^{1)}$ Universitas Islam Riau, ${ }^{2}$ Universitas Riau \\ email: alberuir@edu.uir.ac.id ${ }^{1}$, maria.safriyanti@lecturer.unri.ac.id ${ }^{2}$
}

\begin{abstract}
The metacognitive listening strategy has an important role in the process of enhancing English listening comprehension. This article reviewed six empirical studies related to the impact of metacognitive listening strategy use while learners tried to improve their listening comprehension in different environments. The findings showed that learners used some metacognitive listening strategies to help them to comprehend the listening text tasks. It also indicated that various factors affect learners' successful learning on their listening comprehension improvement. It can be concluded that the metacognitive listening strategy has had a positive impact while they are used regularly in the language learning process.
\end{abstract}

Keywords: Metacognitive, Listening Strategy, English Listening

\section{Introduction}

The involvement of strategy on listening instruction has been one of factors toward the successful learners in listening learning achievement. By using the strategy while learning makes learners to get the effective activity to attain the comprehension, learning, or retention (O'Malley \& Chamot, 1995). Whereas, learning strategy is the beneficial key for opening the way to do language learning process efficiently (Vandergrift, 2004). It is believed that how importance the learning strategy in second language learning and teaching is to be indicated by the successful learners in enhancing their comprehension, insight and new experience during and after having language learning process (Chamot, 2005) Also, it is intended that learning strategies refer 'to any attitudinal plans or behavioral devices that students use to acquire knowledge or skills' (Rost, 2011). It means that through those plans, learners use learning strategy to get transfer of learning improvement from a controlled, pedagogic experience to a more generalized realm.

Furthermore, this paper focused on the metacognitive listening strategy implemented to listening instruction. Theoretically, the term of metacognition originated from the idea of the educational psychologist, Flavell, in which refers to the "knowledge and cognition about cognitive phenomena" (cited in Shih \& Huang, 2019). It is revealed that metacognition has three components: metacognitive knowledge, metacognitive experience, and metacognitive strategy. Particularly, metacognitive strategies refer to the learners who take actions for facilitating learning (Cohen, 2011). Hence, metacognitive strategies could be as strategies that involve "thinking about the learning process, planning for learning, monitoring the learning task, and evaluating how well one has learned" (O'Malley \& Chamot, 1990).

Based on the early concept of metacognition above, scholars have expanded various components of metacognitive strategies. The strategies have been indicators or classifications for researcher to implement them in language learning, especially here toward listening instruction. Strategy researchers classify metacognitive strategies into the following: planning, directed attention, selective attention, self- 
monitoring, and self-evaluation (O'Malley \& Chamot, 1990). However, researchers in the area classify metacognitive strategies into three main groups: planning, monitoring and evaluation (Rost, 2002; Goh, 2008). Therefore, it has appeared the specific metacognitive strategies for listening instruction such as metacognitive awareness listening questionnaire (MALQ) and metacognitive listening strategies instrument (MLSI). Most listening researchers have used MALQ as the main guidance to measure learners' ability in listening comprehension process.

Various studies have proved how importance of metacognitive listening strategies for the benefits of improving students' learning in a language classroom at different environments and skills. The research by using metacognitive learning strategies on listening skill commonly showed that the positive results impacted in enhancing learners listening comprehension at different contexts. Sequentially, it can be seen that students in Saudi Arabia University used problem-solving and directed attention strategies more commonly than the other metacognitive listening strategies; mental translation and person knowledge strategies (Altuwairesh, 2016). Researchers found that there were different strategies learners used in learning their L1 and L2 language acquisition in a small private institution in Missouri (Janusik \& Varner, 2020). Then, metacognitive listening strategies helped Vietnamese learners at Van Lang University to improve their listening comprehension through CALL (Lu, 2021). Next, sophomore students of English education department in Indonesia used their self-regulation in practicing listening skill. It affected them to be aware of the planning process before and during listening as well as knowing how to manage their focus and concentra Judy tion in facing any kinds of listening materials (Savitri \& Anam, 2018). Also, Researches investigated the impact of metacognitive listening strategies used by EFL students in Taiwan at flipped classroom activities in which the results indicated that metacognitive listening strategies use could affect their learning process effectively (Shih \& Huang, 2019). Nevertheless, Researchers, by using metacognitive awareness listening questionnaire (MALQ) toward EFL students at Japanese University, found that there were the moderating effects of listening tests and learner samples while focusing on aspects of metacognitive awareness (In'nami \& Koizumi, 2021). Therefore, this paper, based on the previous researches above, is going to discuss about how metacognitive listening strategies could give positive impacts on listening instruction further at the next section.

\section{Methods}

This paper used descriptive analysis with literature study approach in which six articles that were accessed from international journals and then reviewed by the writers to describe how importance metacognitive listening strategy were at different environments. The articles were analyzed based on some points related to the implementation of metacognitive listening strategy to enhance listening comprehension. Then, its analysis was generalized to show the importance of using this strategy in L2 or foreign listening activity process.

\section{Results and Discussion}

In this section, writers explored intensively on some results in using metacognitive listening strategies based on six articles taken from the international journals. The exploration focused on various impacts and factors that influenced learners' improvements and experiences while learning listening through metacognitive strategies use. The research results have had insights profoundly so that the readers could obtain new understanding to the application of metacognitive strategies for listening instruction.

The first discussion referred to the result of metacognitive listening strategies (Altuwairesh, 2016) used by female Saudi Arabian learners in English listening process. It indicated that problem solving and directed attention strategies were used more than translation and person knowledge strategies. The factors why learners commonly used problem solving were this strategy made them easier to guess the meaning 
of words and to relate what they hear to their previous experiences. Whereas, direct attention strategy use also became dominant strategy used by learners because this helped them to concentrate and stay on the task.

Furthermore, Janusik \& Varner (2020) reported the results of the consistent use of metacognitive strategies for L1 and L2 acquisition implemented by students at a small private institution in Missouri. The results showed that 13 of 21 items on metacognitive listening strategies (MALQ) were used by learners for both L1 and L2 learning process. It means that researchers rediscovered some metacognitive listening strategies which could be used on both language acquisitions. However, researchers found various phenomena during implementing metacognitive listening strategies. It means that they met different responses from learners to 13 items they focused on.

Next, Lu (2021) reported that the application of metacognitive strategies in the computer-assisted listening comprehension course was able to improve the learner's performance. It was proved through Vietnamese learners' awareness while using metacognitive strategies in listening instruction. Students in experimental group used a high awareness of planning and self-evaluation, leading to the necessary strategies to help learners prepare themselves for the upcoming and self-evaluate their effort of listening. It was caused by a set of clear goal and forming a plan in mind even though in the process of pre-listening stage, almost half of the experimental group participants did not remember similar listening texts. Generally, metacognitive strategies applied by learners on listening activity could be able run well while learning process.

Nevertheless, Savitri and Anam (2018) also showed the impact of metacognitive awareness in listening instruction. The English department sophomore students in Universitas Negeri Surabaya were fairly aware of using all aspects in metacognitive strategies and knowledge during the lesson. It can be seen from the average score of the aspect in planning-evaluation indication was students had quite awareness of planning processes before and during listening to an English text, so did evaluating process in achieving their comprehension after listening activities. However, researchers concluded that 'teaching of listening strategies helps students to have greater strategic knowledge, to be able to plan and assess themselves in listening practices, and to be less anxious in dealing with challenges encountered during listening'.

Uniquely, Shih \& Huang (2019) attempted to use metacognitive strategies for Taiwanese EFL students in TOEIC class and used Massive Open Online Courses (MOOC's) as the platform of flipped learning activity. Researchers elaborated out and in class activities for TOEIC lesson. In class activity, students used planning, self-monitoring, and self-evaluation to do their learning especially for setting a goal to their own in-class performance. Out of class learning, learners used self-monitoring strategy to monitor their own learning attitude, learning process, and emotion (how they felt in class). Also, selfevaluation strategy became importance element for learners to examine the effectiveness of their learning. It can be concluded that the implementation of metacognitive strategies in TOEIC class could help the students to be able to have new experiences and attainment during out and in class learning process uniquely and meaningful.

Lastly, In'nami \& Koizumi (2021) examined the relationship between (L2) listening comprehension and metacognitive awareness of students as the samples Japanese University during listening test. They found the moderate results on listening tests and students comprehension while utilizing the aspects of metacognitive awareness. However, research has indicated that metacognitive awareness is nively related to L2 listening comprehension, whereas successful listeners implement numerous strategies to support the cognitive demands of the incoming aural information.

\section{Conclusion}

The importance of metacognitive listening strategies on the process of listening comprehension achievement has been proved through its implementation in listening activities. Metacognitive listening 
strategies have had the crucial roles to support learners easier to follow listening instruction so that a final goal to get comprehension could be able to be attained. However, there were some sub strategies, based on five major components of metacognitive strategies, which showed on the result on the level of moderate. Nevertheless, most results have manifested how importance metacognitive strategies have especially for English listening instruction at different contexts.

The contributions of metacognitive listening strategies toward language learning have given broadly insight and self-confidence for language learners to enhance their ability in comprehending texts' meaning while listening directly. Also, the use of metacognitive strategy could impact on their learning process deeply. Finally, by considering metacognitive listening strategies while learning process, it has helped learners being able to identify their strengths, weaknesses, goals, and actions toward listening comprehension.

\section{References}

Altuwairesh, N. (2016). EFL Saudi undergraduate students' use of metacognitive listening strategies. Arab World English Journal, 7(1), 78-93.

Cohen, A. D. (2011). Strategies in learning and using a second language (2nd ed.). Essex, UK: Longman.

Safitri, W. S. \& Anam, S. (2018). University students metacognitive awareness in listening to english as a foreign language. Advances in Social Science, Education and Humanities Research, vol 222, 222225.

Goh, C. (2008). Metacognitive instruction for second language listening development: Theory, Practice and research implications. RELC, 39(2), 188-213.

In'nami, Y. \& Rkoizumi, R. (2021). The relationship between L2 listening and metacognitive awareness across listening tests and learner samples. International Journal of Listening, 1-18.

Janusik, L. A. \& Varner, T. (2020). (Re) discovering metacognitive listening strategies in L1 contexts: What strategies are the same in the L1 and L2 context? International Journal of Listening, 1-12.

Lu, D. B. (2021). The application of metacognitive strategies in computer-assisted listening comprehension class. Proceedings of the 17th International Conference of the Asia Association of Computer-Assisted Language Learning (AsiaCALL 2021), vol. 533, 149-58.

Rost, M. (2002). Teaching and researching listening. Harlow: Longman.

Rost, M. (2011). Teaching and researching listening. London, UK: Longman.

O’Malley, J. M. \& Chamot, A. (1990). Strategies used by second language learners. Cambridge: Cambridge University Press.

Shih, H. C. J. \& Huang, S. H. C. (2020). College students' metacognitive strategy use in an EFL flipped classroom. Computer Assisted Language Learning, 33(7),755-84. 
Proceeding of International Conference on Language Pedagogy Vol 1. No. 1, pp 1-5, 2021

ISSN: $2809-4808$

DOI: https://doi.org/10.24036/icolp.v1i1.14

Vandergrift, L. (2004). Listening to learn or learning to listen? Annual Review of Applied Linguistics, 24, $3-25$. 